\title{
V International Forum on Teacher Education
}

\section{Psychological and Pedagogical Factors of the Formation of Responsible Attitude to a Future Profession in Students of Higher Pedagogical Institutions}

\author{
Stella G. Grigoryeva (a) ${ }^{*}$, Inna I. Osadchenko (b), Kateryna P. Zhytnukhina (c) \\ (a) Kazan Federal University, 420008, Kazan (Russia), 18 Kremlyovskaya street \\ (b) Pavlo Tychyna Uman State Pedagogical University, 20300, Uman (Ukraine), 2 Sadova street \\ (c) Pavlo Tychyna Uman State Pedagogical University, 20300, Uman (Ukraine), 2 Sadova street
}

\begin{abstract}
The significance of the problem is connected with the debates on the need of a personality's educating in the process of quality professional teacher training, and the real state of formation of responsible attitude to the pedagogical profession in graduates. Proceeding from the analysis of scientific resources and empiric material, the article distinguishes and characterizes mental and physical factors (psychological and pedagogical factors of obstruction (obstacles) and factors of promotion (conditions) of responsible attitude to the future profession in students of higher pedagogical establishments. The authorial complex of mental and physical factors diagnosing the given quality formation (survey, polls, discussion, testing based on the series of authorial questionnaires, survey and tests; pedagogical experiment) was designed and applied. The authors distinguished mental and physical obstacles of responsible attitude to the profession in student teachers: the fear to make a right and appropriate decision in professional educative situations; the lack of stimulation and motivation of important social results of work made by school authority and the state; non-appropriate formation of the responsible attitude to the profession in the process of vocational training etc. The negative level of the operative and activity-based formation component of the demonstration of responsible feeling to the future teacher profession was determined. It may be resulted in incorrect solutions made by students in pedagogical situations. Self-estimation of the formation level of the quality searched was also been appointed. High students' self-estimation level of the formation of responsibility to their profession was stated. It is the significant difference in self-estimation and teachers' estimation (by the mentors and instructors of school practice) of formation level of the quality indicated that is determined. The authors accentuated and experimentally tested psychological and pedagogical terms for the formation of responsible attitude to the future profession in students of higher pedagogical establishments: the necessity of interest stimulating to important social results of work, self-education and self-realization; provision of complete information on the list and compliance of position requirements of a teacher; teaching with plan and organization techniques of one's work and mobile, and appropriate decision-making in educative pedagogical situations in order to avoid fear to act and receive results (actions proceeding from regulatory and legal awareness according to the scheme: 'situation $\rightarrow$ decision-making in accordance with the current legislation $\rightarrow$ result'). It was stated that the responsibility is formed in the process of educative / educational tasks and commission completion that are professionally oriented at curricular and extracurricular time. Educational and educative tasks and commission are to be formed as complex educative pedagogical situations and solved by future teachers. The results of control diagnosing have appeared to be profound: students' self-estimation is adequate if their practical acts are constantly controlled, corrected and estimated by the teachers. The educating of a responsible attitude to the profession is understood as a goal-oriented process that is
\end{abstract}

${ }^{*}$ Corresponding author. E-mail address: ste-grigoreva@yandex.ru 
connected with the formation of professional competency and belief of the correct profession choice (professional identity). The materials of the article are of practical value for the experts in teacher training of a competent worker.

Keywords: formation of responsible attitude to the future profession; feeling of responsibility; educative process; students of higher pedagogical institutions; psychological and pedagogical factors; educative pedagogical situation; educational assignment.

(C) 2019 Stella G. Grigoryeva, Inna I. Osadchenko, Kateryna P. Zhytnukhina

This is an open access article distributed under the terms of the Creative Commons Attribution License (CC BY 4.0), which permits unrestricted use, distribution, and reproduction in any medium, provided the original author and source are credited.

Published by Kazan federal university and peer-reviewed under responsibility of IFTE-2019 (V International Forum on Teacher Education)

\section{Introduction}

The quality and content of the professional future teachers training higher establishments always needs efficient mechanisms of improvement. The purpose of the improvement is the appropriate correlation to time requirements and dynamic society changes. The final result of students' education in higher pedagogical establishment should be a formed personality, open to new experience, active, goaloriented who is able to take an independent choice with responsible attitude to future professional work.

In position duties (competences) of a teacher that are described in their employment contract, responsible attitude to the profession are provided. Instead, the practice shows different data according to promulgation of the information in mass media and the results of previously made polling. The authority of general secondary education establishments, pupils' parents and pupils themselves make claims to teachers about their irresponsible attitude to compliance of the position duties. The claims are also made to higher educational establishments as centres of responsible attitude to future teacher profession formation.

Thus, the significance of the problem is connected with the contradiction of the necessary use of the person's education in the process of qualitative graduate training in a higher pedagogical establishment with the real state formation of responsible attitude to the future profession in the graduates. One of the aspects of the problem is the determination of psychological and pedagogical factors of formation of responsible attitude to the future profession in the students of higher pedagogical establishments.

\section{Purpose and objectives of the study}

The purpose of the study implies detachment, characteristic and experimental control of psychological and pedagogical factors of the formation of responsible attitude to the future profession in the students of higher pedagogical establishments. Here the agents are psychological and pedagogical factors of obstruction (obstacles) and the factors of promotion (conditions) of responsible attitude to the future profession in the students of the studied category.

The objectives of the present study are:

development and implementation of the authorial complex of the diagnostic psychological and pedagogical factors (obstacle and conditions) of responsible attitude formatting to the future profession in the students of pedagogical universities;

self-estimation diagnostics and the formatting level of responsible attitude to the profession in the students of higher pedagogical educational establishments; 
proceeding from empiric material analysis the detaching of psychological and pedagogical conditions for responsible attitude to the future profession in the students of higher pedagogical educational establishments; its theoretical justification and experimental testing.

\section{Literature review}

The detaching of diverse factors of the formation of responsible attitude to the future profession in the students of higher pedagogical institutions in particular is a study problem of scientists of different countries. The Swedish scientists Madeleine Abrandt Dahlgren's and Eva Hammar Chiriac's (2009) analysis of the opinions of teachers, higher pedagogical establishments' graduates and their students on the responsible attitude to the teacher profession is vital in the context of our study. Two scientific positions were determined as a studied dominant. Firstly, on a practical level -the review of formative state of teachers' responsibility feeling in the transiting period from education to professional activity was examined. It coincides with the first working years (proceeding from the generalized outcomes (Eteläpelto \& Saarinen, 2006). Secondly, on a theoretical level - actual unifying of the terms 'responsibility of an educator' and 'professional identity of an educator' was summarizes. The study results show (Dahlgren \& Chiriac, 2009):

general aims of vocational teacher training program do not coincide with real feeling of responsibility and correlation of young specialists on the primary level of professional activity;

lack of perfect correlation between the aims of a curricula in higher educational establishments and the requirements for professional teacher's activity;

transition from the studying at a higher educational establishment to the start of professional activity is not a state of 'shocking transition from theory to practice';

for young teacher mentoring is of great importance, as well as the providing of adapting technologies to professional activity after the studying process.

Darling-Hammond (2010) analysed the American experience of investing in pedagogical education improvement in order to form the responsibility in teachers during the professional activity with their simultaneous accountability. The scientist says, 'The pack of stimulants assumed at the beginning of 2009 includes reinforced vocational training...'(Darling-Hammond, 2010). It means that the projecting of education modernization first of all shows the improvement of vocational teacher training.

In different countries the attention to the aspects of psychological and pedagogical problems of educating in the process of vocational teacher training is paid differently. There the question is not detached. For example, in Finland, a manager-scientist Kansanen (2003) expresses the concern on responsibility transiting for the results of education in schools from a separate teacher to an establishment of general secondary education in general, as a branch. We agree with the above statement: in this case every branch has an objective but not subjective character. It is difficult to find the responsible on the definite pedagogical situation, when the group is responsible but not a separate teacher. On the other hand the above information makes the school stuff work in coordination, control and help each other, in general protecting the school image by the level of general responsible attitude to professional activity.

We consider the responsible attitude to professional activity to be an element of person's leadership quality. In American and Canadian studies the problems of the formation of leadership feeling in students (Leithwood, 2004), the necessity of the state's responsible attitude and its structural branches to educational processes is also vitally described. The pointed may be a sample of professional behavior for every student. But the researchers didn't aim to determine the factors and mechanisms of the formation of 
responsible attitude to the future profession in the students of higher educational pedagogical establishments.

While studying the developmental problem of pedagogical competence of future educators Sabirova (2016) focuses on the emotional component of professional readiness; the formation level of it extends the stress stability and provokes supplementary performing qualities, such as accuracy, discipline and responsibility. It means that the term 'responsible attitude to professional activity' is an element of pedagogical competence. But the obstacles and conditions of the formation of responsible attitude to future profession in the students of pedagogical universities in implementing of these forms of educative work are not analysed.

The theoretical and methodological base of the study also includes the documents of scientific works in psychology on: the structure and functions of the responsibility in a future specialist by Bodrov (1991); the responsibility of a personality as a factor of readiness for professional activity (Scherban \& Raiko, 2013). The Scherban and Raiko's empiric study resulted in the conclusion 'professional responsibility provides the future specialist's possibility to organize his professional development consciously and in goal-oriented manner'. Simultaneously the authors display 'the designing of the programme on the development of responsible attitude to the personality as a factor of readiness for professional activity' as a prospect of further study (Scherban \& Raiko, 2013).

In most studies the term 'responsible attitude to future pedagogical activity' is described casually, in the context of vocational training and formation of students' professional competence. The educative methodology of the described quality in the students of higher pedagogical institutions is aspect analyzed in separated pedagogical conditions of qualitative vocational training: the formation of partnerships with school in the process of school pedagogical practical training hold by the students of the educational establishments in the USA (Darling-Hammond, 2010); the formation of corresponding behavioral acts on the basis of obtaining complex professional pedagogical experience (Andronachea, Bocoúa, Bocoúa, \& Macri, 2014); model use of stimulating of positive attitude to pedagogical profession (Vali, 2015); organisation and holding of special extracurricular lessons as an analogue of pedagogical activity (Tazhbaieva, 2015); the gaining of methods of self-improvement, personal disadvantages removal of the practice (Moldazhanova, Amanova, Tashetova, Bissembaeva, Dzhumazhanova, \& Nurbekova, 2016); the monitoring of vocational training quality by means of psycho and social analysis (Prado de Sousa, Bôas \& Lucia, 2012).

Thus, the question of psychological and pedagogical factors of the formation of responsible attitude to the future profession in the students of higher pedagogical institutions is still open.

\section{Methodology}

Research questions

Having analysed the above mentioned scientific sources, the following state of the theme research is identified:

1. The responsible attitude formation to the future profession is an aspect for the study of educating problem in the qualitative vocational future teacher training in higher pedagogical educational establishments in general and the element of professional pedagogical competence.

2. Obstacles and conditions as psychological and pedagogical factors of the quality formatting are not a subject of any scientific research.

3. In most cases the scientists focus their attention on the vast (the state and school are standards 
of responsible attitude to the profession) and local approaches (an individual character of the phenomenon study; the responsible behavior examples of teacher mentors etc.). Thus, the conditions without obstacles (disadvantages) of the process are studied. It prevents from considering negative factors and a priori denies qualitative vocational future teachers training.

\section{Research methods}

Respondents of the study included 358 students of the 3-rd and 4-th years studying in the specialty 'Primary Education' of the appropriate faculties and the following Ukrainian higher educational institutions: Mykhailo Kotsiubyntskyi Vinnytsia State Pedagogical University (Vinnytsia), Lesya Ukrainka Eastern European National University (Lutsk), Pavlo Tychyna Uman State Pedagogical University (Uman), Hryhorii Skvoroda Kharkiv National Pedagogical University (Kharkiv), Bohdan Hmelnytskyi Cherkassy National University (Cherkassy), Institute of Psychology and Education (Kazan). The choice of courses to teach students was made being based on their skills and erudition on practical activity of the profession by means of durable manufacturing practical training. For controlling and comparative analysis 36 students of the 4-th years studying in the specialty 'Practical Psychologist in Educational Establishments' of the above mentioned universities were involved into the experiment. For cross control and comparative knowledge data 28 lecturers (instructors of students' educational practical training, in the first place) of the listed above universities and 34 teacher mentors of pedagogical practice in general secondary educational establishments were also involved into the survey. Total -62 educational specialists.

Statistical approach was a methodological base of the determination of psychological and pedagogical factors of the formation of responsible attitude to the future professional activity in the students of pedagogical universities. The approach was realized by means of systemic empiric material analysis. Systemic approach was also applied: the process of the formation of responsible attitude to the future professional activity in the students of pedagogical universities was considered as a component of vocational future teacher training system in higher educational establishments. Activity and competence approaches were laid proceeding from the methodology of forming experiment development.

The method of the study had three theoretical and practical stages (theoretical justification and experimental control): stating, forming and controlling. The methods of the study were the following: theoretical (analysis of psychological and pedagogical works and empiric material for comparison and unifying of different scientific views and facts; comparison, systematization and unifying in order to reveal causative-consecutive connections of the studied phenomenon and the detachment of pedagogical conditions for the formation of responsible attitude to the future profession in the students of higher pedagogical establishments); empiric (using questionnaires, polling, discussion, testing based on the series of the authorial questionnaires, survey and tests; pedagogical experiment); statistic - methods of mathematical statistics for determining of statistic importance of the obtained results (arithmetic mean determination).

The method of stating experiment is based on the use of authorial: using questionnaires, testing, polling and discussion in order to diagnose psychological and pedagogical factors (obstruction and obstacles) of formation of responsible attitude to the future profession in the students of higher pedagogical establishments; self-estimation and estimation of the formative level of the mentioned quality. Theoretical principal of the authorial method of questionnaire, testing and polling included the British psychologists' recommendations on testing in the educational branch including 1) disadvantages considering pedagogical testing: limit of the content and sphere of the studied problem; disability of describing separate qualities of 
a student' personality (Raven, 1991); 2) etiquette of pedagogical study (Raven, 1997); 3) peculiarity of social and cyber systems for diagnosing in education (Raven \& Navrotskyi, 2001).

Using authorial questionnaires meant the determination of the following: characteristic of a responsible teacher of a general secondary education establishment, primary school in particular; psychological and pedagogical obstacles in teachers / future teachers for responsible attitude to professional activity and the formation responsible attitude to professional activity in future teachers; psychological and pedagogical conditions of the formation of the mentioned quality in higher educational establishments. The respondents were supposed to give a written answer to five questions on the formation of the responsible attitude components to the future profession in the students of higher pedagogical educational establishments. These components include valuative and motivated (the factors that interrupt the formation and display of the studied quality in the future educational specialist), cognitive (the knowledge of content and the structure of responsible attitude to the future pedagogical profession), operative and activity-based (psychological and pedagogical conditions, behavioral acts of the mentioned quality formation / display). Determination of the forming state of the studied quality cognitive component was analyzed by means of respondents to continue two uncompleted sentences on the characteristic: teacher's personality structure ('The responsible may be a teacher who...') and the studied quality ('The responsibility to professional duties of a teacher is...'). Similarity of the characteristics in respondents' answers was predicted, as well as similarity of the factors in students' answers: obstacles for formatting (in higher educational establishments in the process of vocational training) and display (behavioral acts in the process of educational practical training in general secondary educational establishments) of responsible attitude to the future pedagogical profession. The last question was for the detaching and determining of the ways for causative-consecutive connection removal in the educative process of future teacher training: psychological and pedagogical conditions of the studied quality formation in higher educational establishments.

Authorial testing (including variants of answers) consisted of similar and close questions on the display: the characteristic of teacher's responsibility in a general secondary educational establishment, in primary school particularly; environment and the subject of the quality active formation; psychological and pedagogical obstacles in teachers / future teachers to have a responsible attitude to professional activity. The respondents were offered to choose one or several answers among the given variants (from three to six) in order to clear up the formatting state: valuative and motivated (a subject and environment that provoke and prevent from the formation / display of the future teacher's studied quality), cognitive (the knowledge of feeling structure), operative and activity-based (the obstacles of formation / display of the quality) components of responsible attitude to future teacher profession in the students of higher educational establishments. In order to reveal the formation state of a cognitive element of responsible attitude to the profession it was offered to paraphrase uncompleted sentences of the previous questionnaire as the quality characteristic ('The feeling of responsibility to the profession include...'). It was supposed in the answers of tested students to state the characteristic similarity of responsible attitude to the profession obtained in the previous questionnaire. Besides, the given variants of the answer on the knowledge of the analyzed feeling structure also included the characteristic of three components of the quality for students: valuative and motivated (interest, aspiration), cognitive (knowledge), operative and activity-based (planning and organization; possibility).Specifying of the studied factors obtained in the previous questionnaire was predicted.

We pay attention to the fact that while testing, the respondents were able to choose among two 
given variants of the answer. Thus, the total variants of answers were less than $100 \%$. Since the offered answers in every variants to every question were more than 20 , to make it suitable they were those that jointly summed $25 \%$ of the offers and considered in the study.

Polling (with further discussion) was supposed to be given after the questionnaire had been conducted and the testing in order to reveal: self-estimation and the estimation level of the formation of responsibility to the profession in the students of teacher training universities and the need of the quality formation in the educative process of vocational training in higher educational establishments. The method was of frontal character. The respondents among two questions were offered only one variant ('Yes', 'No', 'I don't know'). Here the total was $100 \%$.

The discussion had been planned for specifying and unifying of formatting psychological and pedagogical conditions of responsible attitude to future profession in the students of higher pedagogical educational establishments. They were supposed to be determined in empiric way.

The method of formatting experiment consisted of two elements: theoretical (via the analysis of unified statistic methods detachment of the obtained empiric material of the formation of responsible attitude to future profession in the students of higher pedagogical educational establishments) and practical (realization of the detached conditions in educative practice of higher pedagogical educational establishments).

The method of controlled experiment is similar to the method of stating experiment (using questionnaires, testing, polling and discussion) in order to compare predicted and real results of selfestimation and the estimation of the formation of responsibility to the future profession in the students of higher pedagogical educational establishments.

\section{Results and Discussions}

Analysis of empiric material of stating stage of the study has proved our expectancies and showed the relative consentient views of different category respondents in the process of being questioned and tested. Thus, further for suitable perceiving we give the average findings from respondents of different categories in general: students of the 3-rd and 4-th years studying in the specialty 'Primary Education' and the students of the 4-th years studying in the specialty 'Practical Psychologist in Educational Establishments' (394 students in total). The final results were taken with arithmetic mean determination.

On the results of using questionnaires, testing and discussion data in accordance with the respondents' views, the responsible teacher is the one who:

- $\quad$ has earnest, scrupulous and devoted attitude to the commission and his work (93.2\%);

- $\quad$ has no fear of taking a decision in difficult pedagogical situations (65.7\%);

- $\quad$ holds a scrupulous preparing for the lessons $(65.7 \%)$;

- $\quad$ is concerned and respects every pupil $(65.7 \%)$;

- $\quad$ fulfils and follows position requirements (44.8\%);

- $\quad$ is engaged in self-education, self-development and self-realization (32.6\%).

In the structure of teacher's personality and responsible attitude to professional duties the respondents determined to be the following main features of character $(100 \%)$ : the desire and fulfilment of the commissions of the school authority and curricula (78.9\%); the ability and skill (having no fear) to take quick, correct and optimal decisions in professional situations (78.9\%); theoretical and methodological knowledge (56.4\%); being organized (44.8\%); being disciplined (44.8\%); teacher's scrupulous attitude to qualitative fulfilment of his professional requirements $(44.8 \%)$; constant self- 
education and self-development $(44.8 \%)$ etc.

Thus, the key terms of responsible attitude for professional activity the future teachers consider 'professional / position requirements and commissions', 'pedagogical situation', 'scrupulosity', 'selfeducation', 'self-development' and etc.

The respondents stated the following psychological and pedagogical obstacles of responsible attitude to teacher professional activity:

discrepancy of present-day reform (the concept 'New Ukrainian School') to the real situation in general secondary educational establishments (100\%);

- $\quad$ fear of taking correct and optimal decisions in professional situations (78.9\%);

- $\quad$ low salaries, medical support on the state level (44.8\%);

- $\quad$ lack of knowledge, skills and desire to take up the post $(44.8 \%)$.

It is urgent to underline the fact that the students concluded he discrepancy of present-day reform (the concept 'New Ukrainian School') to the real situation in general secondary educational establishments except but on the base of the result of manufacturing practice and their discussion in mass media. First of all it proves social activity and indifference of present students about future professional activity.

According to them the following factors prevent from the formation of responsible attitude to the professional activity in the future teachers in higher educational establishments: the older generation's attitude to teaching profession (lecturers of universities and practical teachers) as a negative example (44.8 $\%)$; the perspective of low salary (29.3\%); the lack of motivation to learn and work (29.3\%); lecturers' irresponsible attitude, the lack of skills to inform the students about responsible attitude to the profession of a teacher $(29.3 \%)$.

Simultaneously, $44.8 \%$ of respondents affirmed that in the context of the formation of responsible attitude to the future profession in the students of higher pedagogical educational establishments the type of psychological and pedagogical obstacle depends on every one - individually. We consider the information to be enounced because higher education is a willing process, to contrast with compulsory general secondary education. A priori education in a university is determined by self-education by $60 \%$. That is why stimuli and motivation known to be laid on the stage of training course choice while entering a higher educational establishment. If someone wants 'to find an obstacle for himself' - the reason for truancy - he will definitely find or make it up.

$44.8 \%$ of students are convinced that in order to form responsible attitude to the profession in the future teachers in a higher educational establishment the lecturers should demonstrate a need for: motivation (in the emotional way); implantation the feeling from the 1-st year studying by using practical cases on the classes (lectures in particular); display of persistence in educative work etc.

It is obvious that the respondents noted the environment to provoke the formation of their responsible attitude to teaching profession is: educational environment of the higher educational establishment (56.6 \% - 223 students) they study at; educational environment of the general secondary educational establishment (39.3\% - 155 students) they study at; professional environment of the secondary educational establishment (4.1\% - 16 students) their practical training was held in. The next fact is similar; with slight difference in per cent the future teachers identified the following subjects of the formation of their responsible attitude to the teaching profession: the teachers of the higher educational establishment they study at (55.8\% - 220 students); the teachers of the secondary educational establishment they studied (37.8 \% - 149 students); the pupils they taught during their school practical training ( $2.5 \%$ - 10 students); teacher mentors of the secondary educational establishment their pedagogical practical training was held 
(2.0\% - 8 students); parents of the pupils they taught while their pedagogical practice was being held (1.6 $\%$ - 6 students). Only one student $(0.3 \%)$ identified her parents teachers as a subject of the formation of responsible attitude to the teaching profession.

It is interesting to stress that after having their school practical training held the future teachers noted the following basic psychological and pedagogical, organizational reasons (obstacles) of what with their irresponsible attitude to the professional (future) activity:

lack of stimulating and motivation for important social working results of school authority and the state (low salary and restrained social package) (57.6\% - 227 students);

- $\quad$ fear of taking a responsible decision in professional situations (51.3\% - 202 students);

- $\quad$ lack of formed responsible attitude to the profession in the process of vocational training (50.8\% - 200 students).

The first detached reason is of national and organizational level, the next two reasons are of higher educational establishments' sphere. The first problem (low salary) the student teachers noted having never had a salary - on the level of observation and analysis being under the impression of the communication with the teacher mentors. In the further discussion the students stated that the next two psychological and pedagogical reasons are interdependent: lack of formed responsible attitude to the profession in the process of vocational training resulted in the fear of taking a responsible decision in professional situations.

The next evidence in the survey appeared to be interesting:

- $\quad 59.9 \%$ of students considered themselves to become responsible teachers in future;

- $\quad 23.4 \%$ - hesitated to answer the question;

- $\quad$ the rest $(16.7 \%)$ of the students having their school practical training considered to be irresponsible to the future profession. The reasons for it are different: from full disappointment of the profession choice to the life apathy that has a situational character.

The summarized analysis data of self-estimation level of the formation of responsible attitude to the profession in the students of higher pedagogical educational establishments are presented here diagrammatically (Figure 1):

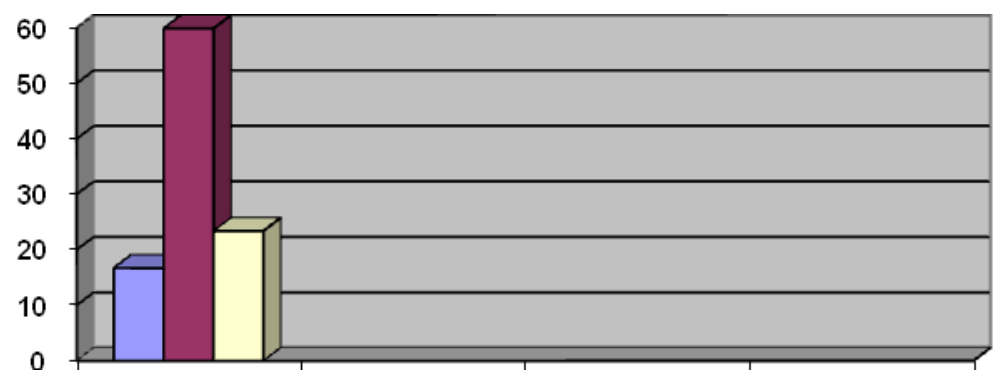

Figure 1. Self-estimation level of the formation of responsible attitude to the profession in the students of higher pedagogical educational establishments (stating experiment)

We consider self-estimation level of the formation of the studied quality to be high. Thus, for cross control and comparative analysis 62 teachers were involved in the study: instructors and teacher 
mentors of students' educational practice. The respondents evaluated the same quality of the students. The outcomes were found to be opposite:

$24.2 \%$ of teacher in the period of school practical training considered the students (future teachers) to be responsible;

- $\quad 16.1 \%$ - hesitated to answer the question;

- the rest of the respondents (59.7\%)after the period of school practical training considered the students (future teachers) to be irresponsible to their profession.

The reasons for the situation are also different: lack of vocational training in a higher educational establishment (lack of knowledge of professional duties: inaptitude to plan and organize the activity); the students being ill-bred; full disappointment of the profession choice; situation or constant life apathy (tiredness and passiveness); lack of students' motivation and the need of responsible feeling training etc. Besides, in discussion the teachers stated high students' self-estimation level of the formation of responsible attitude to the profession caused their inadequate reception of the mistakes while taking decisions in educative pedagogical situations. The students solved the educative pedagogical situations incorrectly, but they were convinced in their right.

The results are presented here diagrammatically (Figure 2):

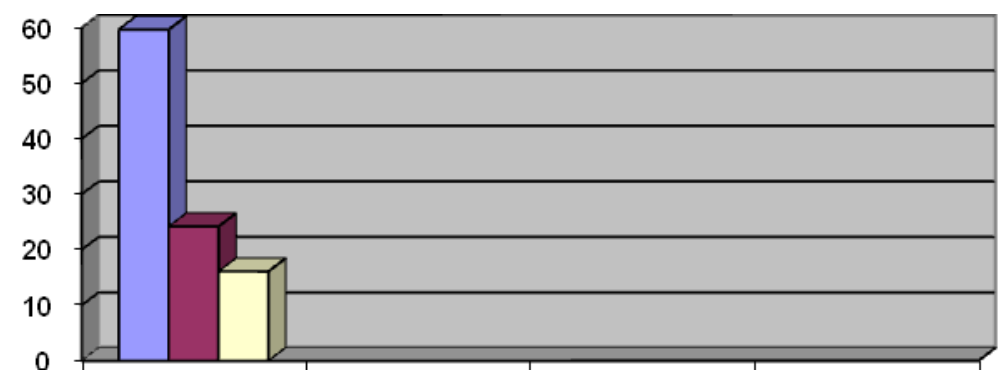

Figure 2. The teachers' estimation level of the formation of responsible attitude to the profession in the students of higher pedagogical educational establishments (stating experiment)

We identify the data to be negative and called them 'misinterpreted (incorrect) students' interpretation of the sense of responsible attitude to the profession'. It is vital to stress that their high selfestimation level is possible to be reasoned by the effort not to be 'worse' than the rest of group-mates, the fear to make teachers angry with low rates, self-estimation and ambitions.

It is hundred per cent that while the survey was being conducted the respondents (both students and teachers) identified the necessity (need) in higher pedagogical educational establishments particularly to form systematically responsible attitude to the teaching profession in future teachers.

Thus, stating experiment helped to find the following contradictions:

In spite of the determined complete need to form responsible attitude to the future profession in the students of higher pedagogical educational establishments, the inadequate students' selfestimation level of the formation of the studied quality was stated.

Though the cognitive structure component of students' formatting responsible attitude to the teaching profession had been explained, operative and activity-based component in the form of 
incorrect decisions in educative pedagogical situations was still unsatisfactory in practice.

The substantiation of the above mentioned outcomes we see in the following:

The students of the 3-rd and 4-th years of studying of higher educational establishments, being respondents, by the moment of the survey in fact had obtained theoretical training and partially practical training.

The skill to make a correct decision in educative pedagogical situations as a component of pedagogical skill is being formed during more than one year. Here the synonym 'professionalism' is appropriate.

Correct decision-making in educative pedagogical situations is a subjective phenomenon and difficult to be estimated because it depends on the context that has a subjective character (is influenced by personal characteristics). That is why practical teachers have their personal views on the decision estimation made by students.

The feeling of responsible attitude to the professional activity as a component of general good breeding of future teachers is determined as a complex phenomenon and requires enlarged diagnostic methods and the duration of diagnosing.

Formatting stage of the pedagogical experiment had two directions: theoretical (the detachment of psychological and pedagogical conditions of the formation of responsible attitude to the profession in the students of higher pedagogical educational establishments) and practical (the realization of the conditions on practice).

Proceeding from the analysis of the obtained empiric material psychological and pedagogical conditions of the formation of responsible attitude to the profession in the students of higher pedagogical educational establishments are highlighted:

the need to stimulate students' interest to important social results of the work, selfeducation and self-realization;

the giving of the information of full value on the list and compliance of the future teacher position requirements;

the teaching of planning and organization techniques of the activity and correct mobile decision-making in educative pedagogical situations in order to prevent the fear of an action and final result (actions on the basis of regulatory and legal awareness according to the scheme: 'situation $\rightarrow$ decision-making in accordance with the current legislation $\rightarrow$ result', in the first place).

Here pedagogical situation (Osadchenko, 2011) is viewed as:

- $\quad$ a didactic unit of vocational future teacher training (a separate educational assignment);

- $\quad$ a unit of teacher's daily professional activity (pedagogical activity - endless list of pedagogical situations).

It is explained that every psychological and pedagogical condition coincides with generally accepted components of the readiness to professional activity: motivated and complete (the first condition), cognitive (the second condition), operative and activity-based (the third condition).

Theoretical justification of the realization of the detached psychological and pedagogical conditions of the responsible attitude formation to the future profession in the students of a pedagogical university is formulated in the following postulates:

1. The feeling of responsibility is formed while educational and educative assignments and commissions of professional course at classes and extracurricular hours are being completed.

Educational and educative assignments that draw on the solving of educative pedagogical 
situations are divided into key (provided for the work program of a separate educational course) and additional assignments. Additional educational and educative assignments are subdivided into:

provided for a work program of a separate educational course as: an additional time job because of different students' rate of basic educational assignments being done; creative complicated assignment to form separate additional qualities in future teachers;

not provided for a work program - context when educative pedagogical situation is formed in the context of another assignments being done or at the lesson in particular.

2. Though we interpret pedagogical activity as an endless list of correlated pedagogical situations, educational and educative assignments and commissions are known to be designed in the form of complex educative pedagogical situations to be solved by future teachers.

For example, while studying the course 'Theory and Methodology of Education' the following assignment is appropriate: Design an educative project for primary school pupils 'Let us Save Environment!'. The example of educational and educative commission: At extracurricular time help practical teachers to organize and conduct the above mentioned project.

Detached psychological and pedagogical conditions were presented to be discussed by the teachers and students. It concluded in the third condition (the practical skills obtaining of responsible attitude to the professional activity of a teacher) to be preferred by the respondents $(65.5 \%)$. The first condition was chosen by $24 \%$ of the respondents, the second $-34.8 \%$. Note: the choice was offered according to the scheme of the possible choice of two among three variants.

The summarized results of the discussion of psychological and pedagogical conditions of the formation of responsible attitude to the professional activity in the students of higher pedagogical educational establishments are presented in the diagram (Figure 3):

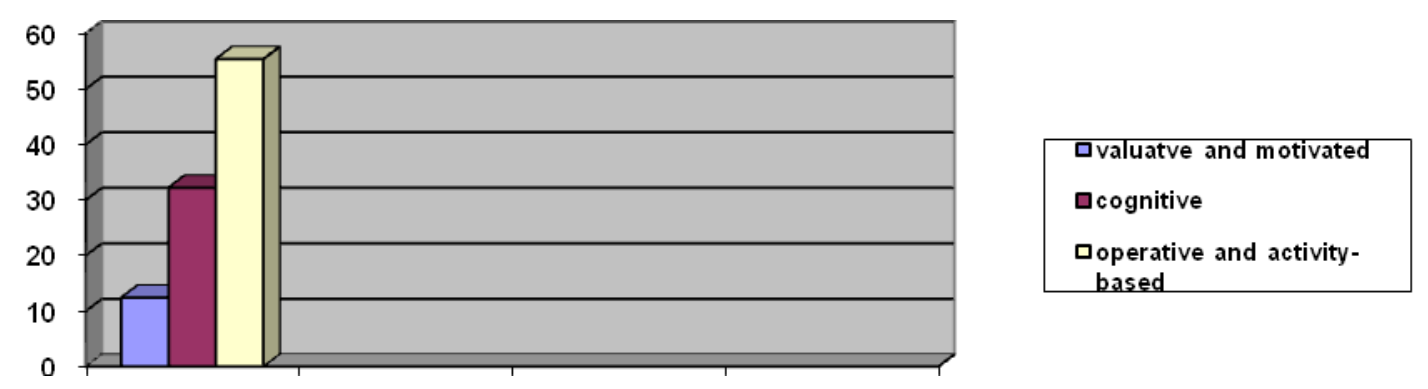

Figure 3. Psychological and pedagogical conditions of the formation of responsible attitude to professional activity in the students of higher pedagogical educational establishments (results of the empiric material analysis)

The realization of the psychological and pedagogical conditions was performed correlate: every other condition provided the realization and continuation of the previous condition realization. That is why at every stage similar forms and methods of educative work with the students were used. For example, one after another the discussions were held in order to provoke in the students the interest to important social result of the work, self-education and self-realization on the following titles: 'What does the term 'responsible attitude to the teacher profession' mean?', 'Causative-consecutive Connections in Pedagogical Activity', 'The Importance of Correct Decision-making in a Pedagogical Situation', 'Responsible: Is There 
an Alternative?', 'Self-confidence Training', 'The Responsibility Training on the Life and Fate of Others', 'Responsibility = Professionalism'. Among the forms of educative work the next appeared to be effective: 'Festival of Pedagogical Skill', the contest 'Super Responsible', the scientific group 'Pedagogical Volunteering', the work-shops of practical teachers on the samples of educative pedagogical situations solving and the importance of pedagogical decision-making; scientific and practical conferences, seminars and trainings of the studied issue; personal and group tutorials, visiting practical lessons to general secondary educational establishments; thematic meetings with outstanding education scholars; educative lessons etc.

The following most effective educative methods are outlined: working out of norms of appropriate behaviour; disputes; different methods of interactive educating (Pometun, 2007) in order to form the ability to make a mobile appropriate decision ('The Decision Tree', 'Semantic Map', problem group solving, role and imitating games, 'Mind Storm', the method 'Press', 'Ideas Auction', 'Take the Position', '1 - $2-4$ All Together', 'Public Hearing', 'Court in the Own Name'); instruction designing for future teachers; conversations, in particular personal conversations on the correct tolerant decision-making; involving in creative cooperation; group commission; analysis of the decisions made; information messages on the samples of responsible attitude to teaching profession via mass media; case-study; designing of the successful situations etc.

At the stage of the cognitive component forming of the future readiness to professional activity educative work on the realizing stages of the purpose and predicted final results in educative pedagogical situation is a vital task for a teacher. It was appropriate to use the methods of educative work with students in the form of: explanation; pedagogical requirement; instruction; discussion; analysis of the responsible decisions taken by practical teachers in educative pedagogical situations; case-study (the examples of educative pedagogical situation solving with the supplement in the form of legal principles of responsible decision-making) etc.

The third psychological and pedagogical condition of the formation of responsible attitude to the future profession in the students of higher pedagogical educational establishments (teaching of the planning and organizing techniques of the activity and correct mobile decision-making in educative professional situations in order to avoid the fear of the action and final result) is a process and result of the first two conditions realization. Here it is interpreted as teaching of the actions on the basis of learning legal principles (cognitive component) in accordance with the scheme: 'educative pedagogical situation $\rightarrow$ decision-making in accordance with the current legislation $\rightarrow$ results'. At the stage the attention was focused on the students' completion of educational (in accordance with the curriculum) and educative situation assignments (in accordance with the plan of educative work and situation activity).

The implementation of the conditions via experiments and surveys was being done during an academic year. At the control stage of the pedagogical experiment the same methods appropriate for stating experiment were used.

To contrast with the stating stage of the experiment the results of the survey appeared to be cardinal:

- $\quad 37.8 \%, 149$ students are assumed as responsible teachers;

- $\quad 31.7 \%, 125$ students hesitate to answer the question;

- $\quad$ the others (30.5\% - 120 students) are assumed as irresponsible in the attitude to the future profession

The following data are of specific features: 
1. The difference appeared not in quantity but in the students' transition from one respondents' group to another.

Thus, most of students 'migrated' from the group 'irresponsible' to the group 'responsible' and vice versa. During the next discussion they explained the fact by the verdicts of pedagogical practice results in general secondary educational establishments. It was done by the self-analysis of decisionmaking in educative pedagogical situations. The fact convinced the students in the reduction of the level of responsible attitude to the future profession (final disappointment in their potential possibilities and a mistaken choice of the profession; exaggeration of their professional competence) etc.; the rise of the responsibility level (the confirmation of sufficient level of their professional competence; the confirmation of the level of potential professional possibilities and correct choice of the profession, etc.).

2. Students' self-estimation is adequate if the constant control, correction and teachers' estimation of their acts are presented.

3. The educating of responsible attitude to the professional activity is a purposeful process that is connected with the formation professional competence and the assurance of correct choice of the profession (professional identity).

The summarized results (controlled experiment) of the analysis of self-estimation level of responsible attitude forming to the profession in the students of higher pedagogical educational establishments are presented in the diagram (Figure 4):
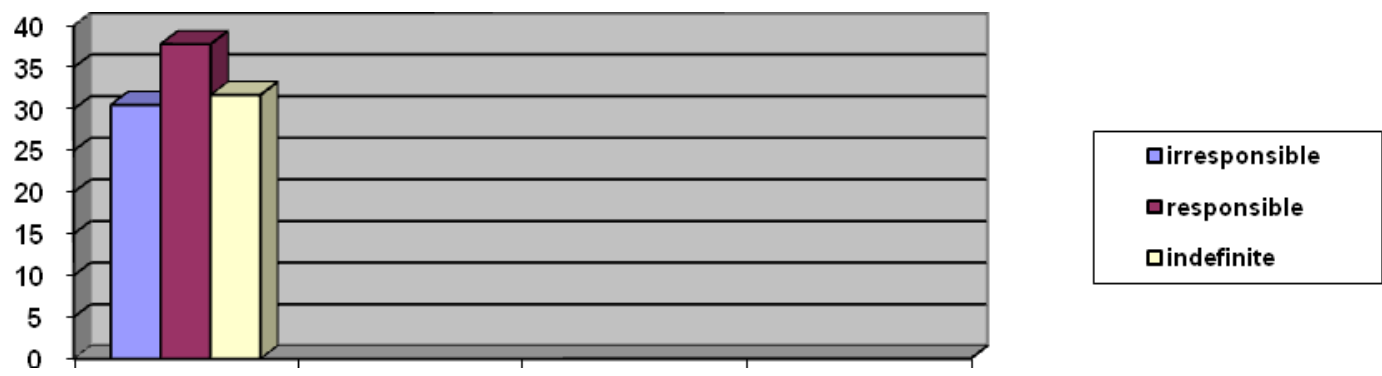

Figure 4. Self-estimation level of responsible attitude forming to the profession in the students of higher pedagogical educational establishments (controlled experiment)

Instead, the teachers (62 instructors and teacher mentors of students' educational practical training) estimated the same students' quality as following:

- $\quad 54.8 \%$ (34 persons) of teachers assume the future teachers as responsible;

- $\quad 25.8 \%$ (16 persons) of teachers assume the students as irresponsible'

- $\quad$ the others $19.4 \%$ (12 teachers) hesitate to answer the question.

The next discussion of the survey results with the teachers demonstrated the reasons for data changes as the reason of:

the rise of confidence level in the students who had appeared as persistent and hardworking in educational and educative assignments completion, even in the cases of incorrect decisionmaking in educative pedagogical situations;

the reduction level of estimation of students' educational and educative assignments 
completion in the case of them being passive and indifferent to the norms obtaining the professional activity

The results are presented in the diagram (Figure 5):

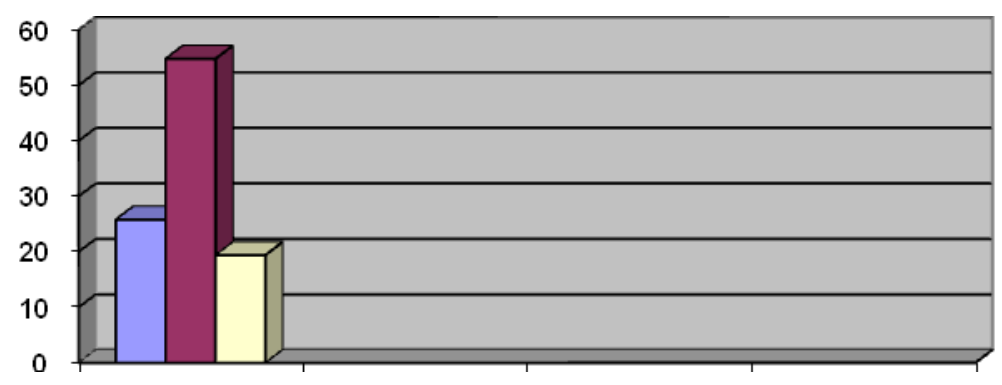

Dirresponsible

口responsible

口indefinite

Figure 5. The teachers' estimation level of responsible attitude forming to the profession in the students of higher pedagogical educational establishments (controlled experiment)

These data are interpreted as more objective to contrast with the results of the stating experiment:

- respondent-teachers appreciated the students' desire for self-improvement, the improvement of responsible feeling as a component of the future teacher personality;

respondent-students understood the sense of the term 'responsible attitude to pedagogical activity' in the following way: they tried to develop the feeling or seldom made a decision on their professional uselessness and the next profession changing.

Having generalized theoretical and practical survey of the theme research, a list of open to question principles are observed:

The formatting level of the phenomenon research is identified with the level of their responsible attitude to the completion of professionally oriented educational / educative assignment and commission. The level characterization means the coordination of estimation and self-estimation of assignment completion (action) and its result. Low self-estimation provokes the fear as an obstacle for responsible attitude to the completion of next assignments.

The key stage of responsible attitude forming to the future profession in the students of higher pedagogical educational establishments while completing educational / educative assignment includes a decision-making in the process of educative pedagogical situation solving. It is the decision that is taken by the future teachers and described as a completion result of educational / educative assignment.

The fear of decision-making while solving an educative pedagogical situation (fear of an action and final result) is denoted as a key psychological and pedagogical obstacle of a responsible attitude forming to the profession in future teachers.

Partially similar problems have already been studied, '...the ways of emotional experience [of young teachers] are possible to be described during a continuum, from the context of educational orientation till the working life context orientation; it proves that different students have different necessities on the views and support in this process'(Dahlgren \& Chiriac, 2009). As a variant to solve the problem researches focus their attention on the perspectives to consider the formatting conditions of responsible feeling and cooperation of future teachers while studying at higher educational establishments. 
The task of an educator is to teach students about the techniques of planning and organizing one's activity and mobile correct decision-making in educative pedagogical situations in order to avoid the fear of an action and final result (first of all, the actions on the basis of learning legal principles in accordance with the scheme: 'situation $\rightarrow$ decision-making in accordance with the current legislation $\rightarrow$ result'). Simultaneously the form and method diversity of the studied quality in higher educational establishments is necessary.

According to Sabirova (2016) students' tutorial work in higher educational establishments is one of the conditions for the component forming in the future teacher competence structure. It stimulates their self-determination in a society and the development of a specialist and professional. She considers voluntary unpaid work on days off ('subotnyk'), compiling of reference books and holding of Teachers' Day. We prove that these forms, methods and tools for educating future teachers are of individual character and local (of higher educational establishment, specialty and a student) and vast type (ethno-dependence).

Though, in general we share the Darling-Hammond's view (2010): educational programs that are not able to perform an appropriate teacher training 'must leave the business of pedagogical education'.

The studied quality is being formed during pedagogical activity and is similar to the term 'professional identity'.

Professional identity is a constant process of experience describing and reinterpreting. It touches both a person and a context; it consists of the sub-identity that is more or less harmonized. Future teachers are known to be active in the process of professional development (Dahlgren \& Chiriac, 2009). We underline the correlation of these terms need further research.

In general the issue of students' attitude to future profession after the compelling of school manufacturing practical training requires detailed study. The problem of correlation of self-estimation level of responsible attitude forming to the future profession in the students of pedagogical universities with the real pedagogical activity is still open. It is urging to describe the adequacy of students' self-estimation in the studied issue. The techniques development of responsible attitude forming to the future profession in the students of pedagogical universities also needs further research.

\section{Conclusion}

Thus, having analyzed scientific sources and empiric material the report has identified and characterized psychological and pedagogical factors (psychological and pedagogical factors of obstruction (obstacles)) and factors of promotion (condition)of responsible attitude to the future profession in the students of higher pedagogical institutions. The findings coincide with the completed assignments:

the authorial complex of diagnosing psychological and pedagogical factors of responsible attitude to the future profession in the students of higher pedagogical educational establishments are identified and implemented. The issues outlined the following psychological and pedagogical obstacles of responsible attitude to the teacher profession in the future teachers: the fear to take correct and optimal decisions in professional educative situations; the lack of stimulation and motivation to important social working results by school authority and the state (low salary and restrained social package); low medical support on the state level; lack of knowledge, skills and desire to take up the position; lack of formed responsible attitude to the profession in the process of vocational training. Unsatisfactory level of students' operative and activity-based component responsible attitude to the future teacher profession in the form of incorrect decision-making in educative pedagogical situations is stated.

self-estimation and the estimation of responsible attitude to the profession in the students 
of higher pedagogical educational establishments are highlighted. The high level of students' selfestimation of responsible attitude to the profession is stated. It led to their inadequate attitude to the mistakes in decision-making in educative pedagogical situations (the students made incorrect decisions in educative pedagogical situations but were convinced in it). A great difference in self-estimation and teachers' estimation (the instructors' and practice mentors') of formatting level of the quality is found out.

on the basis of empiric material analysis psychological and pedagogical conditions for the formation of responsible attitude to the future profession in the students of higher pedagogical educational establishments are detached, theoretically justified and experimentally tested: the need to stimulate students' interest to important social working results, self-education and self-realization; the complete information on the list and the compliance of the future position requirements; the teaching of planning and organizing techniques of one's activity and mobile correct decision-making in educative pedagogical situations in order to prevent the fear of the action and the final result (actions on the basis of regulatory and legal awareness according to the scheme: 'situation $\rightarrow$ decision-making in accordance with the current legislation $\rightarrow$ results' in particular). Every psychological and pedagogical condition coincides with the common component of the readiness for professional activity: valuative and motivated, cognitive, operative and activity-based. It is proved that the feeling of responsibility is formed in the completion professionally oriented educational / educative assignments, commissions at class or extracurricular time. Educational and educative assignments and commissions should be designed in the forms of complex educative pedagogical situations in order to be solved by future teachers. The realization of the described psychological and pedagogical conditions was made in accordance with their connected correlation. The use of following educative methods of work appeared to be reasonable: explanation; pedagogical requirement; instructing; discussion; the analysis of the responsible decisions made by practical teachers in educative pedagogical situations; case-study (the illustration of educative pedagogical situation solving with regulatory and legal principles of appropriate decision-making) etc.

The results of controlled testing were found essential: students' self-estimation was appropriate if constant control, correction and teachers' estimation of their practical actions. The educating of responsible attitude to the professional activity is concerned as purposeful process connected with the formation of professional competence and the conviction of the correct profession choice.

\section{Acknowledgments}

The work is performed according to the Russian Government Program of Competitive Growth of Kazan Federal University.

\section{References}

Andronachea, D., Bocoúa, M., Bocoúa, V., \& Macri, C. (2014). Attitude towards teaching profession. Procedia - Social and Behavioral Sciences, 142(2014), 628-632. URL: https://www.researchgate.net/publication/275543882

Bodrov, V. A. (Eds.). (1991). Professional'naja otvetstvennost' kak psihologicheskaja kategorija sub"ektadejatel'nosti. Psihologicheskie issledovanija problem formirovanija lichnosti professional. Moscow: Institute of Psychology.

Dahlgren, M. A., \& Chiriac, E. H. (2009). Learning for professional life: Student teachers' and graduated teachers' views of learning, responsibility and collaboration. Teaching and Teacher Education: An International Journal of Research and Studies, 25(8), 991-999. 
Eteläpelto, A., \& Saarinen, J. (2006). Developing subjective identities through collective participation. In S. Billett, T. Fenwick, \& M. Somerville (Eds.), Work, Subjectivity and Learning. Understanding learning through working life (pp. 157-177). Dordrecht: Springer.

Darling-Hammond, L. (2010). Teacher Education and the American Future. Journal of Teacher Education, 61(1-2), 35-47.

Kansanen, P. (2003). Teacher Education in Finland: Current Models and New Developments. Retrieved from www.helsinki.fi/ pkansane/Cepes.pdf

Leithwood, K., Louis, K., Anderson, S., \& Wahlstrom, K. (2004). How leadership influences student learning. Learning from Leadership Project. Retrieved from https://www.wallacefoundation.org/knowledge-center/Documents/How-Leadership-InfluencesStudent-Learning.pdf

Moldazhanova, A. A., Amanova, A. A., Tashetova, A. A., Bissembaeva, A. K., Dzhumazhanova, G. K. \& Nurbekova M. A. (2016). Future Teacher-Psychologists' Professional Position as a Component of Professional Competence Formation. International Journal of Environmental \& Science Education, 11(18), 12317-12325.

Osadchenko, I. I. (2011). Teoriia I Praktyka Sutuatsiinoho Navchannia u Pidhotovtsi Maibutnikh Uchyteliv Pochatkovoi Shloly. Uman: PP Zhovtyi.

Pometun, E. I. (2007). Entsyklopediia Interaktyvnoho Navchannia. Kyiv.

Prado de Sousa, C., Bôas, V., \& Lucia, P. S. (2012). Evaluation of teacher training: a psychosocial perspective. Cadernos de Pesquisa, 42(147), 772-789.

Raven, J. (1991). The Tragic Illusion: Educational Testing. Winner of World Education Fellowship Best Book of Year Award. San Francisco, CA: Trillium Press.

Raven, J. (1997). Open Dialogue: Education, Educational Research, Ethics and the BPS. BPS Education Section Review, 21(2), 3-26.

Raven, J. \& Navrotsky, V. (2001). The Development and Use of maps of Socio-Cybernetic Systems to Improve Educational and Social Policy, with particular reference to sustainability. Journal of Mental Changes, 7(1-2), 19-60.

Sabirova, E. (2016). Pedagogical Guest Room as an Educational Form of Students' Pedagogical Competence Development. International Journal of Environmental \& Science Education, 11(6), 1059-1064.

Scherban, T. D., \& Raiko, V. V. (2013). Vidpovidalnist Osobystosti yak Chynnyk Hotovnosti do Profesiinoi Diialnosti. Zbirnyk Naukovykh Prats. Psykholohichni Nauky, 10(91), 335-341.

Tazhbayeva, S. G. (2015). Scientific Basis of the Future Teachers Extracurricular Activities Organization (Educational Aspect). BULLETIN Abay Kazakh National Pedagogical University. Retrieved from https://articlekz.com/en/article/19607

Vali, I. (2015). Attitude towards pedagogical and methodological training and development - a comparative analysis. Procedia - Social and Behavioral Sciences, 180, 820-827. 